\title{
Mass Spectrometry-Based Absolute Quantification of Single Xenopus Embryo Proteomes
}

\author{
Rik G.H. Lindeboom, ${ }^{1,4}$ Arne H. Smits, ${ }^{2,4}$ Matteo Perino, ${ }^{3}$ Gert Jan C. Veenstra, ${ }^{3}$ and Michiel Vermeulen ${ }^{1,5}$ \\ ${ }^{1}$ Department of Molecular Biology, Faculty of Science, Radboud Institute for Molecular Life Sciences, Radboud \\ University, Nijmegen 6500 HB, The Netherlands; ${ }^{2}$ Genome Biology Unit, European Molecular Biology \\ Laboratory, 69117 Heidelberg, Germany; ${ }^{3}$ Department of Molecular Developmental Biology, Faculty of Science, \\ Radboud Institute for Molecular Life Sciences, Radboud University, Nijmegen $6500 \mathrm{HB}$, The Netherlands
}

Early Xenopus development is characterized by a poor correlation between global mRNA and protein abundances due to maternal mRNA and protein loading. Therefore, proteome profiling is necessary to study gene expression dynamics during early Xenopus development. In contrast to mammals, single Xenopus eggs and embryos contain enough protein to allow identification and quantification of thousands of proteins using mass spectrometry-based proteomics. In addition to investigating developmental processes, single egg or blastomere proteomes can be used to study cell-to-cell variability at an unprecedented depth. In this protocol, we describe a mass spectrometry-based proteomics approach for the identification and absolute quantification of Xenopus laevis egg or embryo proteomes, including sample preparation, peptide fractionation and separation, and data analysis.

MATERIALS

It is essential that you consult the appropriate Material Safety Data Sheets and your institution's Environmental Health and Safety Office for proper handling of equipment and hazardous materials used in this protocol.

RECIPES: Please see the end of this protocol for recipes indicated by $<R>$. Additional recipes can be found online at http://cshprotocols.cshlp.org/site/recipes.

Reagents

ABC buffer (50 mm ammonium bicarbonate, freshly prepared)

Britton-Robinson (B\&R) buffer ( $\mathrm{pH} 11 / \mathrm{pH} 8 / \mathrm{pH} 2)<\mathrm{R}>$

Buffer A (0.1\% formic acid)

Buffer B ( $80 \%$ acetonitrile, $0.1 \%$ formic acid)

C18 disks (Empore) and reagents for preparation of C18 StageTips (see Steps 11-14 of Protocol:

Enrichment of Phosphopeptides via Immobilized Metal Affinity Chromatography [Swaney and

Villen 2016])

Cysteine (3\% in 0.25× MMR)

IAA buffer $<\mathrm{R}>$ (freshly prepared, kept in the dark)

MMR buffer $(0.25 \times, \mathrm{pH} 7.4)<\mathrm{R}>$

$\mathrm{NaCl}(0.5 \mathrm{M})$

\footnotetext{
${ }^{4}$ These authors contributed equally to this work.

${ }^{5}$ Correspondence: michiel.vermeulen@science.ru.nl

From the Xenopus collection, edited by Hazel L. Sive.

(C) 2019 Cold Spring Harbor Laboratory Press

Cite this protocol as Cold Spring Harb Protoc; doi:10.1101/pdb.prot098376
} 
R.G.H. Lindeboom et al.

$\mathrm{NaOH}(1 \mathrm{M})$

Strong Anion eXchange (SAX) disk (Empore) and reagents for preparation of 20 plug SAX StageTips

(Rappsilber et al. 2007)

Trifluoroacetic acid (TFA) (10\%)

Trypsin (Promega)

UA buffer $<\mathrm{R}>$ (freshly prepared)

UPS2 standard solution $(0.5 \mu \mathrm{g} / \mu \mathrm{L})<\mathrm{R}>$ (freshly prepared)

WCE-LS (whole cell extract-low salt) buffer $<\mathrm{R}>$ (freshly prepared)

Xenopus laevis eggs (fertilized in vitro)

Equipment

Centrifuge, tabletop (Eppendorf) at $4^{\circ} \mathrm{C}$ and $20^{\circ} \mathrm{C}$

Combitips (Eppendorf)

Filters (30-kDa) (Microcon YM-30)

High-resolution mass spectrometer (e.g., time-of-flight or Orbitrap mass analyzer)

Incubator at $37^{\circ} \mathrm{C}$

Nano-HPLC coupled to a C18 column of $25-30 \mathrm{~cm}$

Pipette tips (Rainin P200) and equipment for preparation of StageTips (see Steps 11-14 of Protocol:

Enrichment of Phosphopeptides via Immobilized Metal Affinity Chromatography [Swaney and

Villen 2016])

Speed vacuum concentrator

Thermoshaker (Eppendorf) at $20^{\circ} \mathrm{C}$

Tubes $(0.2-$ and $1.5-\mathrm{mL})$

This method is based on the work of Smits et al. (2014) (Fig. 1). Yolk-deprived egg or embryo extracts are first digested with trypsin using the so-called Filter-Aided Sample Preparation (FASP) protocol (Wisniewski et al. 2009a) followed by SAX fractionation (Wisniewski et al. 2009b). A protein spike-in is used to facilitate quantification of the protein molecules (Schwanhausser et al. 2011). After sample preparation, peptides are measured in a mass spectrometer. Finally, data analysis is performed using the MaxQuant software suite (Cox and Mann 2008).

Embryo Collection and Lysis

1. Dejelly fertilized eggs by adding $3 \%$ cysteine in $0.25 \times$ Marc's modified Ringer's (MMR). Wash thoroughly four times with $0.25 \times \mathrm{MMR}$ as soon as the embryos start touching each other.

2. Stage the embryos according to Nieuwkoop and Faber (1994), and collect single embryos in separate tubes. Remove any carryover MMR.

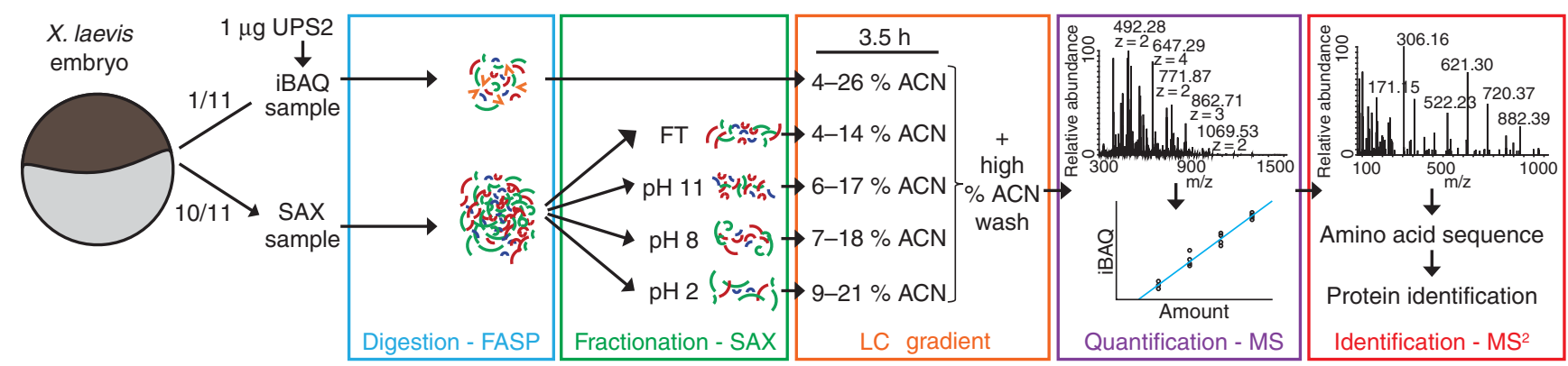

FIGURE 1. Schematic overview of the workflow. Reprinted from Smits et al. (2014) by permission of Oxford University Press. 
3. Add $20 \mu \mathrm{L}$ of WCE-LS buffer per sample and homogenize the embryos by gentle pipetting.

4. Centrifuge the samples at $3500 \mathrm{~g}$ for $5 \mathrm{~min}$ at $4^{\circ} \mathrm{C}$.

5. Transfer the supernatant to a fresh tube without touching the yolk/pigment pellet.

Filter-Aided Sample Preparation

All of the following steps are performed at $20^{\circ} \mathrm{C}$.

6. Add UA buffer to the supernatant from Step 5 to a total volume of $220 \mu \mathrm{L}$. Incubate with gentle shaking for $5 \mathrm{~min}$ in a thermoshaker.

7. Transfer $20 \mu \mathrm{L}$ of the lysate in UA buffer to a new tube.

This is the FASP-iBAQ sample, which is not fractionated and is used for absolute quantification. The residual $200 \mu \mathrm{L}$ is the FASP-SAX sample, which is subjected to fractionation to obtain deep proteome coverage.

8. Add $2 \mu \mathrm{L}$ of UPS2 standard $(0.5 \mu \mathrm{g} / \mu \mathrm{L})$ and $178 \mu \mathrm{L}$ of UA buffer to the FASP-iBAQ sample and mix.

9. Transfer both samples (FASP-iBAQ and FASP-SAX) to two $30-\mathrm{kDa}$ filters. Centrifuge at $11,600 \mathrm{~g}$ for $15 \mathrm{~min}$. Discard the flowthrough (FT).

See Troubleshooting.

10. Add $100 \mu \mathrm{L}$ of IAA buffer to each filter. Incubate for $1 \mathrm{~min}$ in a thermoshaker at $600 \mathrm{rpm}$.

11. Incubate the filters for an additional $20 \mathrm{~min}$ protected from light and without shaking. Centrifuge at $11,600 \mathrm{~g}$ for $15 \mathrm{~min}$.

12. Wash the samples by adding $100 \mu \mathrm{L}$ of UA buffer to each filter. Centrifuge at $11,600 \mathrm{~g}$ for $15 \mathrm{~min}$.

13. Repeat Step 12 two times. Discard the FT.

14. Wash the samples by adding $100 \mu \mathrm{L}$ of $\mathrm{ABC}$ buffer to each filter. Centrifuge at $11,600 \mathrm{~g}$ for $10 \mathrm{~min}$.

15. Repeat Step 14 two times. Discard the FT.

16. Add trypsin to each filter as follows.

i. To the FASP-iBAQ sample, add $0.1 \mu \mathrm{g}$ of trypsin in ABC buffer to a total volume of $40 \mu \mathrm{L}$.

ii. To the FASP-SAX sample, add $1.0 \mu \mathrm{g}$ of trypsin in ABC buffer to a total volume of $40 \mu \mathrm{L}$.

17. Mix the samples at $600 \mathrm{rpm}$ for $1 \mathrm{~min}$ and then incubate in a sealed plastic box containing moist paper towels overnight at $37^{\circ} \mathrm{C}$.

18. Transfer each filter to a new tube. Centrifuge at $11,600 \mathrm{~g}$ for $15 \mathrm{~min}$. Retain the FT.

Steps 18-20 are performed in the same tube. The FT from these steps are combined during centrifugation.

19. Process each filter as follows.

i. To the FASP-iBAQ sample, add $50 \mu \mathrm{L}$ of $0.5 \mathrm{M} \mathrm{NaCl}$. Centrifuge at $11,600 \mathrm{~g}$ for $10 \mathrm{~min}$.

ii. To the FASP-SAX sample, add $50 \mu \mathrm{L}$ of ABC buffer. Centrifuge at 11,600 $\mathrm{g}$ for $10 \mathrm{~min}$.

20. Repeat Step 19.

The FT of $\sim 140 \mu \mathrm{L}$ from each filter represents the tryptic digest of each sample.

Strong Anion eXchange Fractionation (FASP-SAX Sample Only)

21. Prepare a 20 plug SAX StageTip according to Rappsilber et al. (2007).

22. Wash the StageTip by adding $200 \mu \mathrm{L}$ of B\&R buffer ( $\mathrm{pH}$ 11). Centrifuge for $24 \mathrm{~min}$ at $1000 \mathrm{~g}$.

23. Add $140 \mu \mathrm{L}$ of $\mathrm{B} \& \mathrm{R}$ buffer ( $\mathrm{pH} 11)$ and $10 \mu \mathrm{L}$ of $1 \mathrm{M} \mathrm{NaOH}$ to the FASP-SAX sample and mix. The $\mathrm{pH}$ should be between 11 and 12 . 
R.G.H. Lindeboom et al.

24. Transfer the FASP-SAX sample to the StageTip.

25. Centrifuge the sample for $45 \mathrm{~min}$ at $500 \mathrm{~g}$. Retain the FT.

The FT represents the FASP-SAX FT fraction.

See Troubleshooting.

26. Transfer the StageTip to a new tube. Add $200 \mu \mathrm{L}$ of B\&R buffer ( $\mathrm{pH} 11)$ to the StageTip. Centrifuge for $24 \mathrm{~min}$ at $1000 \mathrm{~g}$. Retain the FT.

The FT represents the FASP-SAX ( $p H 11)$ fraction.

27. Repeat Step 26 with $200 \mu \mathrm{L}$ of B\&R buffer (pH 8) to obtain the FASP-SAX (pH 8) fraction.

28. Repeat Step 26 with $200 \mu \mathrm{L}$ of B\&R buffer ( $\mathrm{pH}$ 2) to obtain the FASP-SAX (pH 2) fraction.

Peptide Desalting and Elution

Use all samples (1 FASP-iBAQ + 4 SAX fractions).

29. Prepare, wash and activate five C18 StageTips (or filtration tips) as described in Protocol: Enrichment of Phosphopeptides via Immobilized Metal Affinity Chromatography (Swaney and Villen 2016) (Steps 11-14).

30. Add $10 \mu \mathrm{L}$ of $10 \%$ TFA to each sample. Apply each sample to a separate C18 StageTip.

31. Wash each StageTip by adding $30 \mu \mathrm{L}$ of buffer A. Push the buffer slowly through the StageTips with an airtight, fitted Combitip.

32. Elute the peptides of each sample in a separate $0.2-\mathrm{mL}$ tube by adding $30 \mu \mathrm{L}$ of buffer $\mathrm{B}$ to each StageTip and pushing the buffer slowly through with a Combitip.

33. Concentrate the samples to $\sim 5 \mu \mathrm{L}$ with a speed vacuum concentrator. Add $7 \mu \mathrm{L}$ of buffer $\mathrm{A}$ to each sample (final volume $\sim 12 \mu \mathrm{L}$ ).

\section{Mass Spectrometry}

34. Inject $5 \mu \mathrm{L}$ of each sample into the nano-HPLC coupled to a C18 column of $25-30 \mathrm{~cm}$.

The nano-HPLC acetonitrile gradient varies between the different fractions (Table 1).

35. Acquire mass spectra on a high-resolution mass spectrometer, e.g., time-of-flight or Orbitrap mass analyzer.

For examples of optimized nano-HPLC and mass analyzer settings, see Richards et al. (2015).

Data Analysis

36. Perform data analysis using the MaxQuant software suite (www.maxquant.org). Specify for each FASP-SAX sample the same experiment name but different fraction numbers (assign uneven numbers only). Assign the FASP-iBAQ sample its own experiment name.

37. Upload the FASTA files with protein sequences of Xenopus and UPS2 proteins.

Protein databases from Smits et al. (2014), Wuhr et al. (2014) or UniProt can also be used as a reference for the Xenopus proteome. A FASTA file containing the sequences of the UPS2 proteins can be downloaded from the supplier's webpage.

TABLE 1. Linear nano-HPLC acetonitrile (ACN) gradients for different samples

\begin{tabular}{lccc}
\hline Sample & $\%$ ACN at 0 min & $\%$ ACN at 214 min & $\%$ ACN at 240 min \\
\hline FASP-iBAQ & 4 & 26 & 76 \\
FASP-SAX FT fraction & 4 & 14 & 76 \\
FASP-SAX pH11 fraction & 6 & 17 & 76 \\
FASP-SAX pH8 fraction & 7 & 18 & 76 \\
FASP-SAX pH2 fraction & 9 & 21 & 76
\end{tabular}


38. Empty the contents of the "ibaq.txt" file in the 1.X.X.X_MaxQuant|bin|conf folder.

39. Make sure to enable the "iBAQ" option to facilitate absolute quantification and enable the "match-between-run" option to share peptide identification information between runs.

40. After the MaxQuant analysis, find the quantified protein abundances in the proteinGroups.txt file.

The relative iBAQ quantification of the UPS2 proteins in the FASP-iBAQ sample can be used for absolute quantification of all identified proteins in the fractionated sample.

- A linear regression between the supplied concentrations of the spike-in proteins and the measured iBAQ values can be used to calculate the abundance in femtomoles for all proteins identified in the FASP-iBAQ sample.

- A second linear regression between the absolute abundances of the quantified proteins in the FASP-iBAQ sample and the iBAQ values of same proteins in the FASP-SAX sample can then be used to extrapolate the absolute amounts of all identified proteins in the FASP-SAX sample.

See Troubleshooting.

TROUBLESHOOTING

Problem (Steps 9 and 25): The 30-kDa filters or SAX StageTips are not completely cleared after centrifugation.

Solution: It is essential that the $30-\mathrm{kDa}$ filters and StageTips are completely cleared before continuing to the next step. Increase the centrifugation time accordingly.

Problem (Step 40): The peptide identification rates are low after MaxQuant analysis.

Solution: To boost low peptide identification rates, keep temperature stable in Steps 6-13 to prevent peptide carbamylation by urea buffers.

\section{DISCUSSION}

While RNA-sequencing is often used to study genome-wide gene expression, it is not sufficient when studying early Xenopus development due to decoupled proteome and transcriptome dynamics (Smits et al. 2014; Peshkin et al. 2015). Sample preparation of early-stage Xenopus embryos for mass spectrometry requires proper removal of yolk and protein solubilization with strong detergents (Peuchen et al. 2016). Recent advances in the field of mass spectrometry-based proteomics allowed the study of early Xenopus proteome dynamics at an unprecedented depth (Sun et al. 2014; Wuhr et al. 2014). The relatively large protein content also enabled the first single egg and embryo deep-proteome studies (Smits et al. 2014; Lombard-Banek et al. 2016; Sun et al. 2016).

Britton-Robinson (B\&R) Buffer ( $\mathrm{pH} \mathrm{11/pH} \mathrm{8/pH} \mathrm{2)}$

$40 \mathrm{~mm} \mathrm{H}_{3} \mathrm{PO}_{4}$

$40 \mathrm{~mm} \mathrm{CH}_{3} \mathrm{COOH}$

$40 \mathrm{~mm} \mathrm{H}_{3} \mathrm{BO}_{3}$

Titrate buffer to $\mathrm{pH} 11, \mathrm{pH} 8$, or $\mathrm{pH} 2$ with $1 \mathrm{~m} \mathrm{NaOH}$. Store for up to $2 \mathrm{yr}$ at room temperature. 
R.G.H. Lindeboom et al.

\section{IAA Buffer}

UA buffer $<\mathrm{R}>$ (freshly prepared)

$50 \mathrm{~mm}$ iodoacetamide (IAA)

Prepare fresh before use and keep in the dark.

MMR Buffer (0.25×, pH 7.4)

$22 \mathrm{~mm} \mathrm{NaCl}$

$0.5 \mathrm{~mm} \mathrm{KCl}$

$0.5 \mathrm{~mm} \mathrm{CaCl}_{2}$

$0.25 \mathrm{mM} \mathrm{MgCl}_{2}$

$1.25 \mathrm{~mm}$ HEPES

Store for up to $2 \mathrm{yr}$ at room temperature.

\section{UA Buffer}

8 м urea

$0.1 \mathrm{M}$ Tris- $\mathrm{HCl}(\mathrm{pH} 8.5)$

$50 \mathrm{~mm}$ dithiothreitol

Prepare fresh before use.

UPS2 Standard Solution $(0.5 \mu \mathrm{g} / \mu \mathrm{L})$

UA buffer $<\mathrm{R}>$ (freshly prepared)

UPS2 standard (Sigma-Aldrich) $(0.5 \mu \mathrm{g} / \mu \mathrm{L})$

Dissolve the UPS2 standard $(0.5 \mu \mathrm{g} / \mu \mathrm{L})$ in UA buffer for $>30$ min with gentle shaking at $20^{\circ} \mathrm{C}$.

Prepare fresh before use.

\section{WCE-LS (Whole Cell Extract-Low Salt) Buffer}

\section{$20 \mathrm{~mm}$ Tris- $\mathrm{HCl}(\mathrm{pH} 8.0)$}

$70 \mathrm{~mm} \mathrm{KCl}$

$1 \mathrm{~mm}$ EDTA

$10 \%$ glycerol

$0.1 \%$ IGEPAL CA-630

$5 \mathrm{~mm}$ dithiothreitol (DTT)

$1 \times$ cOmplete EDTA-Free Protease Inhibitors (Roche)

Prepare fresh before use.

\section{REFERENCES}

Cox J, Mann M. 2008. MaxQuant enables high peptide identification rates, individualized p.p.b.-range mass accuracies and proteome-wide protein quantification. Nat Biotechnol 26: 1367-1372.

Lombard-Banek C, Reddy S, Moody SA, Nemes P. 2016. Label-free quantification of proteins in single embryonic cells with neural fate in the cleavage-stage frog (Xenopus laevis) embryo using capillary electropho- resis electrospray ionization high-resolution mass spectrometry (CEESI-HRMS). Mol Cell Proteomics 15: 2756-2768.

Nieuwkoop PD, Faber J. 1994. Normal table of Xenopus laevis (Daudin): A systematical and chronological survey of the development from the fertilized egg till the end of metamorphosis. Garland Pub, New York. 
Peshkin L, Wuhr M, Pearl E, Haas W, Freeman RM Jr, Gerhart JC, Klein AM, Horb M, Gygi SP, Kirschner MW. 2015. On the relationship of protein and mRNA dynamics in vertebrate embryonic development. Dev Cell 35: 383-394.

Peuchen EH, Sun L, Dovichi NJ. 2016. Optimization and comparison of bottom-up proteomic sample preparation for early-stage Xenopus laevis embryos. Anal Bioanal Chem 408: 4743-4749.

Rappsilber J, Mann M, Ishihama Y. 2007. Protocol for micro-purification, enrichment, pre-fractionation and storage of peptides for proteomics using StageTips. Nat Protoc 2: 1896-1906.

Richards AL, Hebert AS, Ulbrich A, Bailey DJ, Coughlin EE, Westphall MS, Coon JJ. 2015. One-hour proteome analysis in yeast. Nat Protoc 10: 701-714.

Schwanhausser B, Busse D, Li N, Dittmar G, Schuchhardt J, Wolf J, Chen W, Selbach M. 2011. Global quantification of mammalian gene expression control. Nature 473: 337-342.

Smits AH, Lindeboom RG, Perino M, van Heeringen SJ, Veenstra GJ, Vermeulen M. 2014. Global absolute quantification reveals tight regulation of protein expression in single Xenopus eggs. Nucleic Acids Res 42: 9880-9891.
Sun L, Bertke MM, Champion MM, Zhu G, Huber PW, Dovichi NJ. 2014. Quantitative proteomics of Xenopus laevis embryos: Expression kinetics of nearly 4000 proteins during early development. Sci Rep 4: 4365.

Sun L, Dubiak KM, Peuchen EH, Zhang Z, Zhu G, Huber PW, Dovichi NJ. 2016. Single cell proteomics using frog (Xenopus laevis) blastomeres isolated from early stage embryos, which form a geometric progression in protein content. Anal Chem 88: 6653-6657.

Swaney DL, Villen J. 2016. Enrichment of phosphopeptides via immobilized metal affinity chromatography. Cold Spring Harb Protoc doi:10.1101/ pdb.prot088005.

Wisniewski JR, Zougman A, Nagaraj N, Mann M. 2009a. Universal sample preparation method for proteome analysis. Nat Methods 6: 359-362.

Wisniewski JR, Zougman A, Mann M. 2009b. Combination of FASP and StageTip-based fractionation allows in-depth analysis of the hippocampal membrane proteome. J Proteome Res 8: 5674-5678.

Wuhr M, Freeman RM Jr, Presler M, Horb ME, Peshkin L, Gygi S, Kirschner MW. 2014. Deep proteomics of the Xenopus laevis egg using an mRNAderived reference database. Curr Biol 24: 1467-1475. 


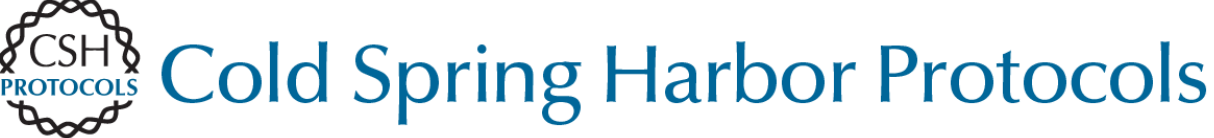

\section{Mass Spectrometry-Based Absolute Quantification of Single Xenopus Embryo Proteomes}

Rik G.H. Lindeboom, Arne H. Smits, Matteo Perino, Gert Jan C. Veenstra and Michiel Vermeulen

Cold Spring Harb Protoc; doi: 10.1101/pdb.prot098376 originally published online August 13, 2018

\begin{tabular}{|c|c|}
\hline $\begin{array}{r}\text { Email Alerting } \\
\text { Service }\end{array}$ & Receive free email alerts when new articles cite this article - click here. \\
\hline $\begin{array}{l}\text { Subject } \\
\text { Categories }\end{array}$ & $\begin{array}{l}\text { Browse articles on similar topics from Cold Spring Harbor Protocols. } \\
\text { Cell Biology, general (1382 articles) } \\
\text { Chromatography (47 articles) } \\
\text { Developmental Biology ( } 728 \text { articles) } \\
\text { Liquid Chromatography (51 articles) } \\
\text { Mass Spectrometry (78 articles) } \\
\text { Proteins and Proteomics, general (575 articles) } \\
\text { Proteomics (66 articles) } \\
\text { Xenopus (210 articles) }\end{array}$ \\
\hline
\end{tabular}

